J. Clin. Chem. Clin. Biochem.

Vol. 25, 1987, pp. $553-559$

(C) 1987 Walter de Gruyter \& Co.

Berlin - New York

\title{
Estimation of the Production Rates of Serum Aminoterminal Propeptide of Type III Procollagen and Laminin in Human Fibrotic Liver
}

\author{
By A. M. Gressner, J. Kropf \\ Abteilung für Klinische Chemie und Zentrallaboratorium, Philipps-Universität Marburg, Marburg, FRG and
}

\section{W. Tittor}

Stoffwechselklinik der LVA Württemberg, Akademisches Lehrkrankenhaus der Universität Heidelberg, Bad Mergentheim

(Received March 25/June 22, 1987)

Summary: The concentrations of laminin, a high molecular weight non-collagenous glycoprotein of basement membranes, and of the $\mathrm{N}$-terminal propeptide of type III procollagen were determined in the serum of the liver outflow vascular region (hepatic vein) and of a peripheral vein (cubital vein) in patients with chronic liver diseases (fibrosis, cirrhosis, unspecified histology; $n=173$ ), in order to determine their secretion rates from the injured livers. The mean levels of laminin $(1.84 \mathrm{kU} / \mathrm{l})$ and of procollagen peptide $(28.0 \mu \mathrm{g} / \mathrm{l})$ in hepatic vein were significantly higher (about $9.5 \%$ at $\mathrm{p}<0.02$, and $37 \%$ at $\mathrm{p}<0.001$, respectively) than those in the periphery (1.68 kU/1 and $20.4 \mu \mathrm{g} / \mathrm{l}$, respectively). In chronic liver diseases, however, laminin and procollagen peptide concentrations in the hepatic vein were lower than or equal to those in the cubital vein in $18 \%$ and $27 \%$ of patients, respectively. The highest regional differences of the concentrations were noted in cirrhotic subjects. The serum levels of laminin $\left(r_{s} 0.93\right)$ and of procollagen peptide $\left(r_{s} 0.73\right)$ in hepatic and in cubital vein are highly positively correlated $(\mathrm{p}<0.001)$, but the levels of procollagen peptide in hepatic vein are only weakly but still significantly statistically related with those of laminin $\left(r_{s} 0.446, p<0.001\right)$. Similarly, the hepatic-cubital venous concentration differences of both proteins are weakly $\left(r_{s} 0.312\right)$ but significantly $(p<0.001)$ correlated. On the basis of several assumptions we estimated secretion rates from the livers of $120 \mathrm{U} \cdot \mathrm{min}^{-1}$ for laminin, and $5.7 \mu \mathrm{g} \cdot \mathrm{min}^{-1}$ for procollagen peptide. These data support the view that the chronically injured human liver is highly active in producing serum laminin and procollagen peptide, which are measured in elevated concentrations in the serum of liver fibrotic and cirrhotic subjects. The results point to a high turnover of these connective tissue-derived proteins in the circulation.

\section{Introduction}

Fibrosis, a main hịstological fẹture of liver cirrhosis, is characterized biochemically by several fold increases of the amounts and changes of the molecular composition of various types of collagens (İ, IIII, IV, V, VI), noncollagenous (structural) glycoproteins (fibronectin, laminin), proteoglycans (heparan sulphate, chondroitin sulphate, dermatan sulphate), and glycosaminoglycans (hyaluronic acid) in the extracellular space of the liver tissue (1). Their accumulation is accomplished by a stimulated production in various parenchymal and non-parenchymal types of liver cells, but the mechanisms of enhanced synthesis are only poorly understood (2). Along with the development of liver fibrosis, the concentrations of some connective tissue-derived proteins or their cleavage products increase in serum, an observation which has been exploited for clinical chemical diagnosis and follow-up of fibrogenesis $(3,4)$. Among these parameters, the determination of the concentration of the 
aminoterminal propeptide of type III procollagen has found wide clinical application in the monitoring of patients with chronic liver diseases, who risk development of fibrosis and cirrhosis $(3-6)$. The level of procollagen peptide in serum has been shown to be closely correlated with the activity of the fibrogenic process $(7-14)$ and the extent of the fibrotic transformation $(7,15-17)$ of chronically injured liver. Recently, elevated concentrations of laminin, a high molecular weight $\left(M_{\mathrm{r}} \sim 1 \cdot 10^{6}\right)$ noncollagenous glycoprotein constituent of basement membranes (18, 19), have been measured in the sera of fibrotic and cirrhotic liver patients; the extent of the elevation was reported to be correlated with the severity of organ fibrosis $(17,20-24)$ and the degree of portal hypertension $(21-24)$. The mechanism of the elevation of the connective tissue proteins in serum of fibrotic liver patients is not clear. It may be due to enhanced synthesis and fractional secretion by the producing cell types of the liver, stimulated break-down and discharge into the circulation of intercellularly deposited matrix proteins, or by reduced clearance of circulating connective tissue proteins originating from nonhepatic sources. In the following study we attempted to define the production of serum procollagen peptide and laminin in fibrotic livers by measuring their concentrations selectively in the liver outflow and comparing them with the respective levels in peripheral venous regions. Based on several assumptions, we tried to estimate the order of magnitude of the contribution of fibrotic livers to the serum pool of laminin and procollagen peptide, respectively.

\section{Materials and Methods}

Patients

Hospitalized patients with chronic liver diseases $(n=173)$ of various aetiologies (50\% chronic alcohol consumption, $22 \%$ posthepatitis $\mathrm{B}, 28 \%$ miscellaneous and unknown) were subdivided into those with histologically verified fibrosis $(n=55)$ and cirrhosis $(n=41)$, and those $(n=77)$ with unspecified histology where a liver biopsy specimen was not available. The hepatic vein of all patients was catheterized for measurement of portal vein pressure (25). Patients were informed about the procedure and gave their consent. Venous catheterization was performed with a Swan-Ganz balloon catheter starting from the right femoral vein using Seldinger's technique (26). The tip of the catheter was introduced into the right hepatic vein under fluoroscopic control.

\section{Specimen collection}

Blood was aspirated simultaneously from the hepatic vein and from the periphery (cubital vein). All patients were in an overnight fasting state. After allowing the blood to clot for $1 \mathrm{~b}$ at room temperature serum was prepared by centrifugation and stored at $-70^{\circ} \mathrm{C}$ for a maximum of one month before the assays were performed.
Assay of N-terminal propeptide of type III procollagen

The propeptide was analysed in various dilutions $(1: 5,1: 20$, $1: 50)$ of serum by a radioimmunoassay for the aminoterminal propeptide of type III procollagen (Behring-Hoechst, Frankfurt, FRG). Details of the assay have been described previously $(27-29)$. The within-run coefficient of variation (CV) was $4.9 \%(x=12 \mu \mathrm{g} / 1 ; n=40)$; the day-to-day $C V$ was $7.2 \%(x$ $=5.0 \mu \mathrm{g} / \mathrm{l} ; \mathrm{n}=36)$. The upper limit' of the reference range of procollagen peptide in serum is $\leqslant 12 \mu \mathrm{g} / 1$ (29).

\section{Assay of laminin}

The concentration of the glycoprotein was determined with a competitive radioimmunoassay (Behring-Hoechst, Frankfurt, FRG), details of which are reported elsewhere (30). The antibody is directed against antigenic determinants of the pepsinresistant fragment P1 of laminin (31). The coefficients of variation of the within-run and day-to-day imprecisions were $3.1 \%$ and $4.9 \%(x=2.0 \mathrm{kU} / \mathrm{I})$, respectively. The inaccuracy ranged from $-12 \%$ to $+11 \%$. During storage at $-20^{\circ} \mathrm{C}$ no significant loss of laminin was noted. According to the manufacturer of the test reagents, the concentrations of laminin are given in arbitrary $\mathrm{kU} / \mathrm{l}$ because an international standard of laminin is not available; $1 \mathrm{U}$ is defined as the mean quantity of laminin per $\mathrm{ml}$ serum in a group of obviously healthy persons and corresponds to about $0.230 \mu \mathrm{g}$ (31). The reference range of laminin in serum (2.5-97.5 percentile) was determined previously to be $0.81-1.43 \mathrm{kU} / 1$ (median $1.04 \mathrm{kU} / \mathrm{l}$ ) (21).

Estimation of liver production rates of laminin and propeptide of type III procollagen

Synthesis and/or secretion rates of the respective connective tissue proteins in the liver were calculated from the difference between the antigen concentrations in the liver outflow vascular region (vena hepatica) and in a peripheral vein (vena cubitalis), based on the following assumptions:

i) a blood perfusion rate of the liver of $1.50 \mathrm{l} / \mathrm{min}$ per $1.73 \mathrm{~m}^{2}$ body surface area (32),

ii) liver inflow concentrations of the proteins corresponding to those measured in the cubital vein,

iii) identical concentrations of the respective proteins in portal vein (providing 70 to $75 \%$ of total liver blood supply) and hepatic artery ( 25 to $30 \%$ of blood supply),

iv) a mean haematocrit of 0.50 (33), and

v) a plasma volume of 0.025 to $0.045 \mathrm{l} / \mathrm{kg}$ body weight (34) corresponding to a total body $(70 \mathrm{~kg}$ ) plasma volume of about 2.51 .

\section{Statistical methods}

Differences between groups were tested with the Mann-Whitney-Wilcoxon U-test; $\mathrm{p}<0.05$ was considered to be statistically significant. Correlations are described with Spearman's rank correlation coefficient $\left(r_{s}\right)(35)$.

\section{Results}

Concentrations of laminin and procollagen peptide in hepatic vein and cubital vein of patients with chronic liver diseases

The mean serum laminin concentrations in hepatic $(1.84 \mathrm{kU} / \mathrm{l})$ and cubital $(1.68 \mathrm{kU} / \mathrm{l})$ vein of all patients with chronic liver diseases, were significantly ( $p$ 
$<0.001$ ) elevated if compared with the reference concentration of the glycoprotein in cubital vein $(0.81-1.43 \mathrm{kU} / \mathrm{l})$ (tab. 1). In both vascular regions the concentrations of laminin were found to be higher in cirrhotic subjects than in patients with mere liver fibrosis (tab. 1). Qualitatively similar results were obtained for the procollagen peptide; the mean concentrations of this peptide in hepatic and cubital vein of cirrhotic patients were higher than those measured in liver fibrotic individuals (tab. 2). The mean procollagen peptide concentrations in hepatic $(28.0 \mu \mathrm{g} / \mathrm{l})$ and in cubital $(20.4 \mu \mathrm{g} / \mathrm{l})$ vein of the total population of patients were greatly elevated compared with the reference range $(2-12 \mu \mathrm{g} / \mathrm{l})$ of the procollagen fragment in serum.

There was a significant correlation $(p<0.001)$ between the concentrations of the respective proteins in hepatic vein and cubital vein, but the correlation for procollagen peptide $\left(r_{s} 0.734\right)$ was lower than that for laminin $\left(r_{s} 0.93\right)$ (figs. 1, 2). A weak $\left(r_{s} 0.446\right)$ but still significant statistical relation $(p<0.001)$ was observed between the concentrations of laminin and procollagen peptide in hepatic vein (fig. 3 ).

In the majority of patients with chronic liver diseases the concentrations of laminin and procollagen peptide were found to be higher in the hepatic vein than in the peripheral vascular region (tab. 3). Fractions of only 0.18 and 0.27 of all patients with chronic liver diseases had concentrations of laminin and procollagen peptide, respectively, in the hepatic vein which were equal to or lower than those in the cubital vein (tab. 3). The fractions of positive and negative hepatic-cubital venous concentration differences of both matrix proteins varied slightly between the different groups of liver diseases (tab. 3). The frequency distribution of the quantitative differences of the laminin and procollagen peptide concentrations, respectively, between hepatic and cubital vein is shown

Tab. 1. Serum concentrations (mean values \pm S.D.) of laminin in cubital and hepatic vein and estimates of the synthesis/ secretion rates by the liver in the various groups of chronic liver diseases. The estimations of the synthesis rates are based on several assumptions described in materials and methods. n. s. = not significant.

\begin{tabular}{|c|c|c|c|c|c|c|}
\hline \multirow[t]{2}{*}{ Group of liver diseases } & \multirow{2}{*}{$\begin{array}{l}\text { Number } \\
\text { of patients }\end{array}$} & \multicolumn{4}{|c|}{ Serum laminin concentration $(\mathrm{kU} / \mathrm{l})$} & \multirow{2}{*}{$\begin{array}{l}\text { Synthesis/ } \\
\text { secretion rates } \\
\left(U \cdot \min ^{-1}\right)\end{array}$} \\
\hline & & $\begin{array}{l}\text { cubital vein } \\
\text { (CV) }\end{array}$ & & $\begin{array}{l}\text { hepatic vein } \\
\text { (HV) }\end{array}$ & $\mathrm{HV}-\mathrm{CV}$ & \\
\hline Unspecified histology & $7 \overline{7}$ & $1.51 \pm 0.53$ & $\mathrm{p}<0.05$ & $1.70 \pm 0.67$ & $0.19 \pm 0.28$ & 143 \\
\hline Fibrosis & 55 & $1.57 \pm 0.46$ & n.s. & $1.64 \pm 0.47$ & $0.07 \pm 0.19$ & 53 \\
\hline Cirrthosis & 41 & $2.16 \pm 0.84$ & n.s. & $2.35 \pm 0.93$ & $0.19 \pm 0.40$ & 143 \\
\hline Total & 173 & $1.68 \pm 0.65$ & $p<0.02$ & $1.84 \pm 0.75$ & $0.16 \pm 0.29$ & 120 \\
\hline
\end{tabular}

Tab. 2. Serum concentrations (mean values \pm S.D.) of procollagen peptide in cubital and hepatic vein and estimates of the synthesis/secretion rates by the liver in the various groups of chronic liver diseases. The estimations of the synthesis rates are based on several assumptions described in materials and methods. n.s. $=$ not significant

\begin{tabular}{|c|c|c|c|c|c|c|}
\hline \multirow[t]{2}{*}{ Group of liver diseases } & \multirow{2}{*}{$\begin{array}{l}\text { Number } \\
\text { of patients }\end{array}$} & \multicolumn{4}{|c|}{ Serum procollagen peptide concentration $(\mu \mathrm{g} / \mathrm{l})$} & \multirow{2}{*}{$\begin{array}{l}\text { Synthesis/ } \\
\text { secretion rates } \\
\left(\mu \mathrm{g} \cdot \mathrm{min}^{-1}\right)\end{array}$} \\
\hline & & $\begin{array}{l}\text { cubital vein } \\
\text { (C.V) }\end{array}$ & & $\begin{array}{l}\text { hepatic vein } \\
\text { (HV) }\end{array}$ & $\mathrm{HV}-\mathrm{CV}$ & \\
\hline Unspecified histology & 41 & $18.2 \pm 10.4$ & $\mathrm{p}<0.03$ & $24.6 \pm 16.5$ & $6.4 \pm 11.5$ & 4.8 \\
\hline Fibrosis & 28 & $20.8 \pm 9.6$ & n.s. & $27.2 \pm 15.1$ & $6.4 \pm 11.5$ & 4.8 \\
\hline Cirrhosiṣ & 24 & $23.9 \pm 9.2$ & $p<0.005$ & $34.5 \pm 14.8$ & $10.6 \pm 8.1$ & 8.0 \\
\hline Total & 93 & $20.4 \pm 10.1$ & $\mathrm{p}<0.001$ & $28.0 \pm 16.0$ & $7.6 \pm 10.6$ & 5.7 \\
\hline
\end{tabular}




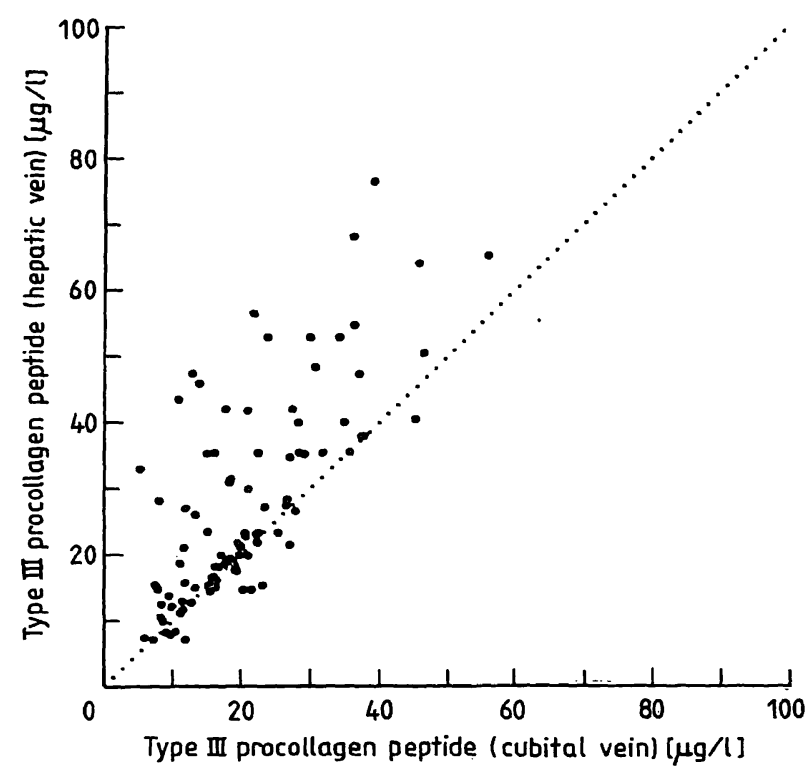

Fig. 1. Correlation of the serum concentrations of procollagen peptide between hepatic vein and cubital vein in all patients with chronic liver diseases $(n=93)$. Spearman's rank correlation coefficient: $r_{s}=0.734$ (p $<0.001)$.

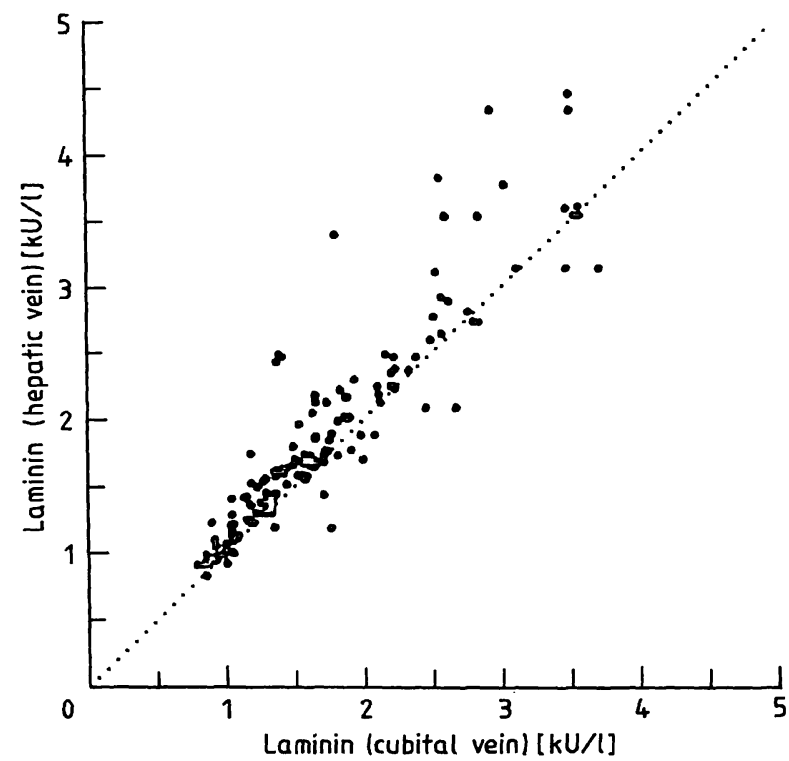

Fig. 2. Correlation of the serum concentrations of laminin between hepatic vein and cubital vein in all patients with chronic liver diseases $(n=173)$. Spearman's rank corrclation coefficient: $r_{s}=0.93(p<0.001)$.

in figure 4. It is demonstrated that about half of the patients had concentrations of laminin in the hepatic vein, which were 10 to $20 \%$ higher than those in the cubital vein. Larger regional concentration differences were observed more frequently for procollagen peptide than for laminin, but negative concentration differences of laminin occurred less frequently than those of procollagen peptide (fig. 4).

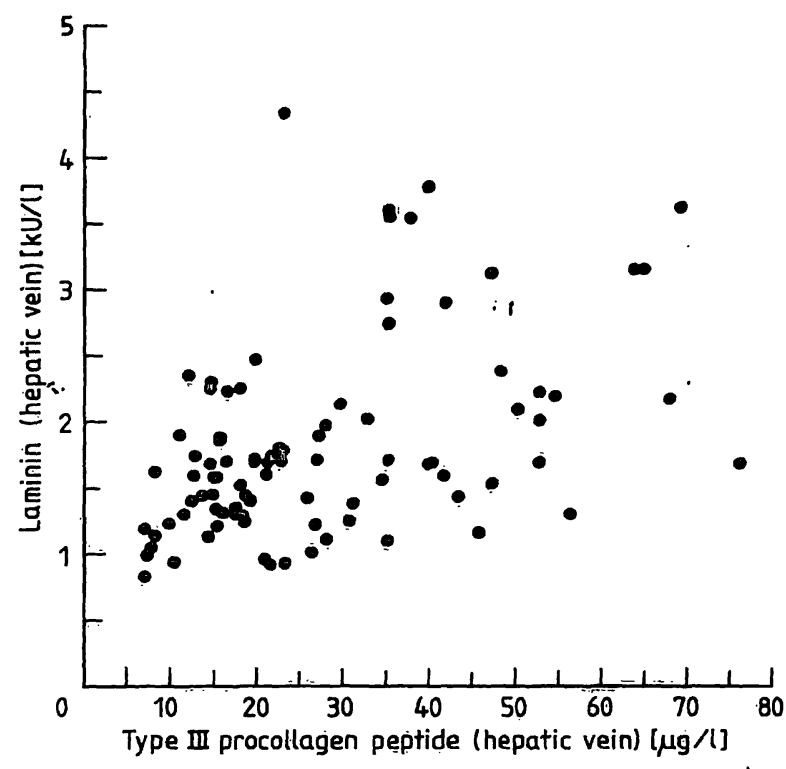

Fig. 3. Scatter plot of the serum concentrations of procollagen peptide and laminin in hepatic vein of all patients with chronic liver diseases $(n=93)$. Spearman's rank correlation coefficient: $r_{s}=0.446(p<0.001)$.

Tab. 3. Frequency distribution (fraction of total) of positive and negative differences between the serum concentrations of laminin and procollagen peptide (P-III-P) in hepatic vein and cubital vein in patients of various groups of liver diseases.

\begin{tabular}{llllll}
\hline $\begin{array}{l}\text { Group of liver } \\
\text { diseases }\end{array}$ & \multicolumn{3}{l}{ Quality of difference } \\
\cline { 2 - 3 } & negative & & positive \\
\cline { 2 - 3 } \cline { 5 - 6 } & laminin & P-III-P & & laminin & P-III-P \\
\hline $\begin{array}{l}\text { Unspecified histo- } \\
\quad 0.13\end{array}$ & 0.32 & 0.87 & 0.68 \\
$\begin{array}{l}\text { Fibrosis } \\
\text { Cirrhosis }\end{array}$ & 0.22 & 0.29 & 0.78 & 0.71 \\
$\begin{array}{l}\text { All chronic liver } \\
\quad \text { diseases }\end{array}$ & 0.24 & 0.17 & 0.76 & 0.83 \\
& & 0.27 & 0.82 & 0.73 \\
\hline
\end{tabular}

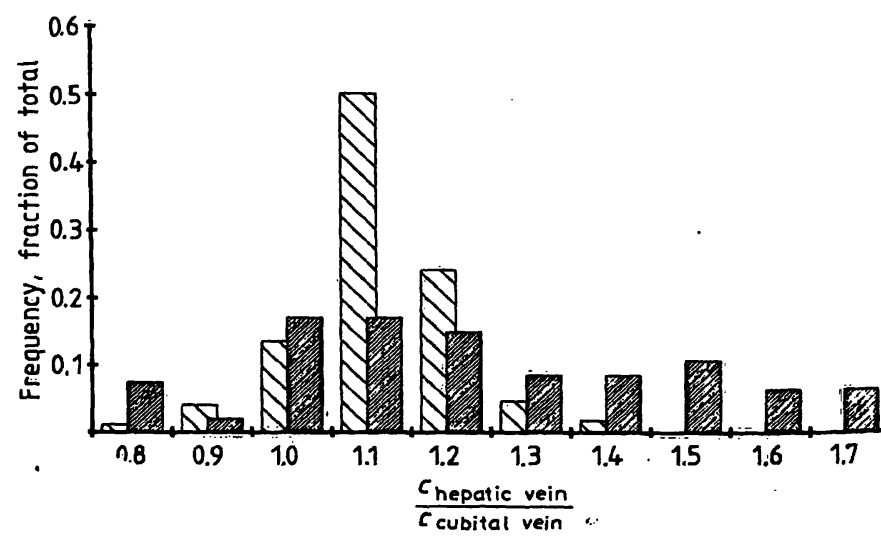

Fig. 4. Frequency of the relative differences $\Delta_{c}$ of the concentrations of laminin $(n=173 ; \square)$ and procollagen peptide $(n=93 ; \square)$ in serum from the hepatic vein and cubital vein in all patients with chronic liver diseases. 
The hepatic-cubital venous concentration differences of laminin and procollagen peptide in cirrhotic patients were higher than those found in liver fibrotic subjects (tabs. 1, 2). In fibrotic patients, the concentration differences of both proteins were statistically non-significant; the same was true for laminin in liver cirrhotic subjects. In all patients with chronic liver diseases the mean concentration differences of laminin and of procollagen peptide were found to be 0.16 $\mathrm{kU} / \mathrm{l}(\mathrm{p}<0.02)$ and $7.6 \mu \mathrm{g} / \mathrm{l}(\mathrm{p}<0.001)$, respectively, but a large statistical variation was noted. The largest regional concentration differences observed for laminin and procollagen peptide were $1.59 \mathrm{kU} / \mathrm{l}$ and 37.4 $\mu \mathrm{g} / \mathrm{l}$, respectively, both being measured in liver cirrhotic patients. There was a weak but significant correlation between the hepatic-cubital venous concentration differences of procollagen peptide and la$\operatorname{minin}\left(r_{s} 0.312, p<0.001\right)$. The regional concentration differences were not correlated with the aetiology of the chronic liver disease, the portal venous pressure, or the stages of oesophageal varices; there was also no correlation with a number of routine clinicalchemical liver parameters (aspartate and alanine aminotransferases, $\gamma$-glutamyl-transferase, bilirubin) (data not shown).

Estimation of the production rates of serum laminin and procollagen peptide in fibrotic and cirrhotic livers

Based on the above described assumptions, the net production (synthesis and/or secretion) rates of $120 \mathrm{U} \cdot \mathrm{min}^{-1}$ for laminin and $5.7 \mu \mathrm{g} \cdot \mathrm{min}^{-1}$ for procollagen peptide were calculated for the total population of patients with chronic liver diseases. These values were slightly higher in cirrhotic and lower in liver fibrotic subjects (tabs. 1, 2). The chronically injured liver would therefore be able to produce the $4200 \mathrm{U}$ of laminin present in the total body plasma volume of 2.51 (calculated from the mean concentration in the cubital vein) in about $35 \mathrm{~min}$; this time would be longer for fibrotic (79 $\mathrm{min}$ ) and shorter for cirrhotic livers (29 min). Similarly, the total plasma pool of procollagen peptide of $51 \mu \mathrm{g}$ would be replenished by the chronically injured liver in about 9 min; a slightly longer time (11 min) would be required by fibrotic and a shorter time $(6.4 \mathrm{~min})$ by cirrhotic livers.

\section{Discussion}

It is well established by quantitative biochemical data and immunofluorescence (-peroxidase) staining methods that in chronically injured liver an excessive intercellular deposition of collagens (36-42) and of laminin $(43,44)$ occurs. Type III collagen is distributed uniformly within the lobulus and is present in the space of Disse and around the central vein (45). Laminin, which is a main constituent of all basement membranes $(18,19)$, is normally (almost) absent from the Disse space $(43,46)$. In alcoholic liver injury, however, laminin appears in the Disse space, where it can be intensely stained by immunologic methods, together with the light and electron microscopic appearance of basement membranes beneath the endothelial cell layer of the sinusoid $(43,44,47)$. The accumulation of the matrix proteins in fibrotic liver is brought about by their stimulated synthesis and secretion in some sinusoidal types of liver cells (e.g. fat-storing cells, endothelial cells) (48) but recent findings point to parenchymal liver cells (hepatocytes) as additional sources of collagen production in the liver $(42,49-57)$. It is conceivable that during the process of intercellular deposition of newly formed laminin and procollagen peptide, fractions of the respective proteins escape into the circulation, thereby contributing to elevated concentrations in the liver outflow. In accordance with this hypothesis it is shown in the present study that the mean concentrations of laminin and procollagen peptide in the serum of the liver outflow vascular region are respectively $9.5 \%$ and $37.2 \%$, higher than those in a peripheral vein. Similar regional differences in the concentrations of these proteins were also observed in a preliminary study with a limited number of patients (23). Assuming liver inflow concentrations (similar in portal vein and hepatic artery) of laminin and procollagen peptide identical with those measured in the systemic circulation, we conclude from these data that the fibrosing liver secretes a significant fraction of serum laminin and procollagen peptide. It cannot be decided whether this secretion is due to a fraction of newly synthesized matrix proteins escaping into the blood stream before deposition in the lobulus or to discharge of matrix protein (fragments) during breakdown of hepatic connective tissue and tissue remodeling. The latter possibility might be not a remote alternative since it was shown that type III procollagen can be deposited extracellularly without prior cleavage of the aminoterminal extension peptide $(58-60)$. Thus, elevation of the procollagen peptide in serum, although mainly a split product of the maturation pathway of collagen (61) does not necessarily reflect increased de novo synthesis of this type of collagen, but may originate from the degradation of tissue procollagen present in extracellular fibrils $(62,63)$. The heterogeneity of aminoterminal propeptide-related antigens in human serum might be 
accomplished by the different origins and pathways of the propeptide $(62-64)$. The weak correlations between the concentrations and concentration differences of laminin and procollagen peptide indicate that the above described mechanisms of their relative elevations in the hepatic vein are likely to be different. On the basis of our assumptions, the data do not point to an impairment of clearance functions of the fibrotic liver as a cause of raised matrix protein levels in serum; if this were the case, a relative decrease of the respective concentrations in hepatic vein would be anticipated. The latter mechanism was held responsible for the significant elevation of the hyaluronate concentration in the serum of cirrhotic and fibrotic liver patients $(65,66)$. In fact, the concentrations of hyaluronate in hepatic vein were found to be significantly lower than those in other vascular beds in man, which allowed the calculation of a net hepato-splanchnic clearance of this connective tissue compound of $0.250 \mathrm{l} / \mathrm{min}$ (67). Elucidation of the role of the liver in the clearance of laminin and procollagen peptide would require the determination of their concentrations selectively in the hepatic artery and portal vein; for obvious reasons this would present insurmountable difficulties.

Calculation of the production rates of the serum fractions of laminin and procollagen peptide in human fibrotic liver from the present data must be preliminary. The results may, in fact, be erroneous, because the actual liver inflow concentrations of both proteins cannot be measured, the levels of procollagen peptide and laminin in the portal vein (which contributes about $75 \%$ of total hepatic blood flow) and the hepatic artery (which provides the remaining $25 \%(68)$ ) could be different, and the blood perfusion rates of normal liver (32) applied here might be not valid for fibrotic livers. Keeping in mind these serious limitations, the estimates of relatively high production rates would imply a rather active turnover of the matrix proteins in the circulation, which supports results of a previous report suggesting a fast catabolism of circulating aminopropeptide even in healthy humans (69). The half-lives of circulating laminin and procollagen peptide deduced from our data are in the same order of magnitude as those of hyaluronate, which were estimated to be $5.8 \mathrm{~min}(67)$ and $2.7 \mathrm{~min}$ (70) in non-liver diseased persons and about $28 \mathrm{~min}$ in patients with primary biliary cirrhosis (70). Interestingly, the production rates of both laminin and procollagen peptide were found to be higher in cirrhotic subjects than in patients with mere liver fibrosis, an observation, which might have a number of as yet speculative pathobiochemical explanations. Because it is unlikely that the liver is the only' source of laminin and procollagen peptide in serum, the catabolic and/or elimination rates of these proteins could be even higher than those deduced from our data. Presently, the mechanisms and organs participating in the elimination of circulating procollagen peptide and laminin are not known. A low mölecular weight fraction of procollagen peptide is eliminated with the urine $(69,71)$ but laminin $\left(M_{r} \sim 1 \cdot 10^{6}\right)$ and its pepsin-resistant fragment $\mathrm{P} 1\left(M_{\mathrm{r}} 0.25-0.44\right.$. $\left.10^{6}\right)(72)$, which might occur in the blood stream $(20,21)$, do not pass the glomerular membrane. As mentioned above a clearance function of the liver for both proteins cannot be strictly ruled out by our data because their immediate liver proximal concentrations are not known. Although the present study supports the view of the fibrotic liver as the active producing organ of a significant fraction of serum laminin and procollagen peptide, it is obvious that more detailed information is needed before definite conclusions can be drawn on its role in the handling of circulating matrix proteins.

\section{References}

1. Rojkind, M. \& Kershenobich, D. (1986) In: The Liver Annual (Arias, I. M., Frenkel, M. \& Wilson, J. H. P., eds.) Elsevier Science Publishers B. V.

2. Gressner, A. M. (1986) Med. Welt 37, 898-905.

3. Hahn, E. G. (1984) J. Hepatol. 1, 67-73.

4. Gressner, A. M. (1987) Ann. Clin. Biochem., 24, 283-292.

5. Rojkind, M. (1984) Hepatology 4, 977-978.

6. Weigand, K., Zaugg, P.-Y., Frei, A. \& Zimmermann, A. (1984) Hepatology 4, 835-838.

7. Frei, A., Zimmermann, A. \& Weigand, K. (1984) Hepatology 4, 830-834.

8. Bolarin, D. M., Savolainen, E.-R. \& Kivirikko, K. I. (1984) Eur. J. Clin. Invest. 14, 90-95.

9. Roberts, F. D., Halliday, J. W., Cooksley, W. G. E., Sandford, N., Karawi, M., Shahed, M., Mohamed, A. \& Powell, L. W. (1986) J. Gastroenterol. Hepatol. 1, 333-338.
10. Morelli, A., Vedovelli, A., Fiorucci, S., Angelini, G. P., Fini, C., Palmerini, C. A. \& Floridi, A. (1985) Clin. Chim. Acta 148, 87-95.

11. Torres-Salinas, M., Pares, A., Caballeria, J., Jimenez, W., Heredia, D., Bruguera, M. \& Rodes, J. (1986) Gastroenterology $90,1241-1246$.

12. Annoni, G., Cargnel, A., Colombo, M. \& Hahn, E. G. (1986) J. Hepatol. 2, 379-388.

13. Schuppan, D., Dumont, J. M., Kim, K. Y., Hennings, G. \& Hahn, E. G. (1986) J. Hepatol. 3, 27-37.

14. McCullough, A. J., Stassen, W. N., Wiesner, R. H. \& Czaja, A. J. (1987) J. Lab. Clin. Med. 109, 55-61.

15. Raedsch, R., Stiehl, A., Waldherr, R., Mall, G., Gmelin, K., Götz, R., Walker, S., Czygan, P. \& Kommerell, B. (1982) Z. Gastroenterologie 20, 738-743. 
16. Tanaka, Y., Minato, Y., Hasumura, Y. \& Takeuchi, J. (1986) Digest. Dis. Sci. 31, 712-717.

17. Sato, S., Nouchi, T., Worner, T. M. \& Lieber, C. S. (1986) J. Am. Med. Ass. 256, $1471-1473$.

18. Mark von der, K. \& Kühl, U. (1985) Biochim. Biophys. Acta 823, 147-160.

19. Abrahamson, D. R. (1986) J. Pathol. 149, 257-278.

20. Niemelä, O., Risteli, L., Sotaniemi, E. A. \& Risteli, J. (1985) Eur. J. Clin. Invest. 15, 132-137.

21. Gressner, A. M. \& Tittor, W. (1986) Klin. Wochenschr. 64, 1240-1248.

22. Gressner, A. M., Tittor, W., Negwer, A. \& Pick-Kober, K.H. (1986) Clin. Chim. Acta 161, 249-258.

23. Gressner, A. M., Tittor, W. \& Negwer, A. (1986) Hepatogastroenterology 33, 191-195.

24. Gressner, A. M., Tittor, W. \& Kropf, J. (1987) Gut, submitted.

25. Groszmann, R. J., Glickman, M., Blei, A. T., Storer, E. \& Conn, H. O. (1979) Gastroenterology 76, 253-258.

26. Bützow, G. H., Dörner, V., Ossenberg, F. W. \& Becker, K. (1974) Dtsch. Med. Wochenschr. 99, 1599-1601.

27. Niemelä, O. (1985) Clin. Chem. 31, 1301-1304.

28. Niemelä, O., Risteli, L., Sotaniemi, E. A. \& Risteli, J. (1982) Clin. Chim. Acta 124, 39-44.

29. Rohde, H., Vargas, L., Hahn, E., Kalbfleisch, H., Bruguera, M. \& Timpl, R. (1979) Eur. J. Clin. Invest. 9, 451-459.

30. Pick-Kober, K.-H., Negwer, A. \& Gressner, A. M. (1985) J. Clin. Chem. Clin. Biochem. 23, 572-573.

31. Brocks, D. G., Strecker, H., Neubauer, H. P. \& Timpl, R. (1986) Clin. Chem. 32, 787-791.

32. Bradley, S. E., Ingelfinger, F. J., Bradley, G. P. \& Curry, J. J. (1945) J. Clin. Invest. 24, 890-897.

33. Scully, R. E., Mark, E. J. \& McNeely, B. U. (1986) New Engl. J. Med. 314, 39-49.

34. Tietz, N. W. (1982) Fundamentals of Clinical Chemistry. W. B. Saunders Company, Philadelphia.

35. Sachs, L. (1984) Angewandte Statistik: Anwendung statistischer Methoden. Springer-Verlag, Berlin.

36. Rojkind, M., Giambrone, M.-A. \& Biempica, L. (1979) Gastroenterology 76, 710-719.

37. Rojkind, M. \& Martinez-Palomo, A. (1976) Proc. Natl. Acad. Sci. USA 73, 539-543.

38. Orrego, H., Medline, A., Blendis, L. M., Rankin, J. G. \& Kreaden, D. A. (1979) Gut 20,673-679.

39. Orrego, H., Blendis, L. M., Crossley, I. R., Medline, A., MacDonald, A., Ritchie, S. \& Israel, Y. (1981) Gastroenterology 80, 546-556.

40. Murata, K., Kudo, M., Onuma, F. \& Motoyama (1984) Hepato-gastroenterology $31,158-161$.

41. Martinez-Hernandez, A. (1985) Lab. Invest. 53, 166-186.

42. Clement, B., Grimaud, J.-A., Campion, J.-P. Deugnier, Y. \& Guillouzo, A. (1986) Hepatology 6, 225-234.

43. Hahn, E., Wick, G., Pencev, D. \& Timpl, R. (1980) Gut 21, 63-71.

44. Martinez-Hernandez, A. (1985) Lab. Invest. 53, 166-186.

45. Geerts, A., Geuze, H. J., Slot, J.=W., Voss, B., Schuppan, D., Schellinck, P. \& Wisse, E. (1986) Histochem. 84, 355362.

46. Martinez-Hernandeż, A. (1984) Lab. Invest. 51, 57-74.
47. Bianchi, F. B., Biagini, G., Ballardini, G., Cenacchi, G., Faccani, A., Pisi, E., Lasche, R., Liotta, L. \& Garbisa, S. (1984) Hepatology 4, 1167-1172.

48. Friedman, S. L., Roll, F. J., Boyles, J. \& Bissell, M. (1985) Proc. Natl. Acad. Sci. USA 82, $8681-8685$.

49. Guzelian, P. S. \& Diegelmann, R. F. (1979) Exp. Cell. Res. $123,269-279$.

50. Guzelian, P. S., Qureshi, G. D. \& Diegelmann, R. F. (1981) Collagen Rel. Res. 1, 83-93.

51. Diegelmann, R. F., Guzelian, P. S., Gay, R. \& Gay, S. (1982) Science 219, 1343-1345.

52. Saber, M. A., Zern, M. A. \& Shafritz, D. A. (1983) Proc. Natl. Acad. Sci. USA 80, 4017-4020.

53. Clement, B., Emonard, H., Rissel, M., Druguet, M., Grimaud, J.-A., Herbage, D., Bourcl, M. \& Guillouzo, A. (1984) Cell. Molec. Biol. 30, 489-496.

54. Diegelmann, R. F. \& Lindblad, W. J. (1985) Fundamental and Applied Toxicology 5, 219-227.

55. Sakakibara, K. \& Igarashi, S. (1985) In: Pathobiology of hepatic fibrosis (Hirayama, C. \& Kivirikko, K. I., eds.) Elsevier Science Publishers.

56. Sakakibara, K., Ooshima, A., Igarashi, S. \& Sakakibara, J. (1986) Virchows Arch. Pathol. Anat. 409, 37-46.

57. Chojkier, M. \& Filip, M. (1986) J. Clin. Invest. 78, $333-$ 339.

58. Fleischmajer, R., Timpl, R., Tuderman, L., Raisher, L., Wiestner, M., Perlish, J. S. \& Graves, P. N. (1981) Proc. Natl. Acad. Sci. USA 78, 7360-7364.

59. Wick, G., Brunner, H., Penner, E. \& Timpl, R. (1978) Int. Arch. Allergy Ap̀pl. Immunol. 56, 316-324.

60. Sato, S., Leo, M. A. \& Lieber, C. S. (1986) Am. J. Pathol. $122,212-217$.

61. Prockop, D. J., Kivirikko, K. I., Tuderman, L. \& Guzman, N. A. (1979) New Engl. J. Med. 301, 13-23.

62. Niemelä, O., Risteli, L., Sotaniemi, E. A. \& Risteli, J. (1982) Clin. Chim. Acta 124, 39-44.

63. Niemelä, O., Risteli, L., Sotaniemi, E. A. \& Risteli, J. (1983) Gastroenterology 85, 254-259.

64. Galambos, M. R., Collins, D. C. \& Galambos, J. T. (1985) Hepatology 5, 38-42.

65. Engström-Laurent, A., Lööf, L., Nyberg, A. \& Schröder, T. (1985) Hepatology 5, 638-642.

66. Frebourg, T., Delpech, B., Bercoff, E., Senant, J., Bertrand, P., Deugnier, Y. \& Bourreille, J. (1986) Hepatology 6, 392395.

67. Bentsen, K. D., Henriksen, J. H. \& Laurent, T. C. (1986) Clin. Science 71, $161-165$.

68. Campra, J. L. \& Reynolds, T. B. (1982) In: The Liver: Biology and Pathobiology (Arias, I., Popper, H., Schachter, D. \& Shafritz, D. A., eds.) pp. 627-645, Raven Press, New York.

69. Rohde, H., Langer, I., Krieg, T. \& Timpl, R. (1983) Collagen Rel. Res. 3, 371-379.

70. Fraser, J. R. E., Engström-Laurent, A., Nyberg, A. \& Laurent, T. C. (1986) J. Lab. Clin. Med. 107, 79-85.

71. Niemelä, O. (1985) Clin. Chem. 31, 1301-1304.

72. McCarthy, J. B., Basara, M. L., Palm, S. L., Sas, D. F. \& Furcht, L. T. (1985) Cancer and Metastasis Rev. 4, 125152.
Prof. Dr. med. A. M. Gressner Abteilung für Klinische Chemie und Zentrallaboratorium Philipps-Universität Baldingerstraße D-3550 Marburg 
